\title{
In vitro anti-proliferative activity of selected nutraceutical compounds in human cancer cell lines
}

\author{
Endalkachew Nibret ${ }^{1,2^{*}}$, Sonja Krstin ${ }^{3}$ and Michael Wink ${ }^{3}$
}

\begin{abstract}
Objective: We investigated the anti-proliferative or cytotoxic activities of five nutraceutical compounds: allyl isothiocyanate, $\beta$-carotene, caffeine, capsaicin, and lupanine that we consume respectively, for example, from mustard seeds, carrot, coffee, pepper, and lupin seeds against cancer cell lines (human colon: HCT 116 p53 wild type, HCT 116 p53-/- and lymphoblastic: CEM/CCRF, CEM/ADR5000).

Result: Out of the five compounds tested in vitro, capsaicin and $\beta$-carotene were more cytotoxic than the other three compounds against the four cancer cell lines. The most potent nutraceutical compound was capsaicin and it exerted its highest cytotoxicity against HCT $116 \mathrm{p} 53-/$ - with $\mathrm{IC}_{50}$ value of $19.67 \pm 0.06 \mu \mathrm{M}$. It is worth considering capsaicin for further development of anticancer drug against both colon and leukemia cancer types.
\end{abstract}

Keywords: Colorectal cancer, Lymphoblastic cancer, Nutraceuticals

\section{Introduction}

Cancer is the second leading cause of death globally. In 2018 alone, an estimated 9.6 million deaths occurred due to cancer. Approximately $70 \%$ of these deaths occurred in low-and middle-income countries [1].

Some nutraceuticals that are consumed as food or part of food are known to provide health benefit in prevention and control of various infectious- and non-infectious diseases (e.g. cancer). To date, some nutraceuticals have been approved for clinical use [2, 3]. Still now, the search for new chemical entities having health benefit from food items is being intensively investigated. Quite recently, a few promising nutraceuticals entered clinical trials [4-6]. In addition, nutraceuticals could also exert negative effects in the consumer, which are often neglected in studies.

\footnotetext{
*Correspondence: endtg2002@yahoo.com

${ }^{1}$ Department of Biology, Science College, Bahir Dar University, P.O.Box 79, Bahir Dar, Ethiopia

Full list of author information is available at the end of the article
}

In the present study, we evaluated five nutraceuticals (allyl isothiocyanate, $\beta$-carotene, caffeine, capsaicin, lupanine) and the known anti-cancer drug, vinblastine, against four different types of cancer cell lines. Allyl isothiocyanate is one of the components of mustard paste prepared from mustard seeds and horseradish and is known for its pungency. It is derived from the glucosinolate sinigrin, which is found in some Brassica vegetables including cabbage, brussels sprouts, kale and cauliflower [7]. $\beta$-Carotene is one of the major carotenoids with antioxidant properties in our diet and its major sources of dietary include green leafy vegetables as well as orange and yellow fruits and vegetables [8]. Caffeine is an alkaloid, which is known for its mild stimulant and is traditionally consumed from sources like coffee, teas, cola, and chocolate [9]. Capsaicin is the active major alkaloid of hot chili and is responsible for pungent feeling of peppers in the genus Capsicum. Peppers are mainly consumed as food additives because of their unique pungency, aroma, and color [10]. Lupanine is one of the major quinolizidine alkaloids responsible for bitterness

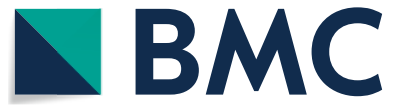

(c) The Author(s) 2021. This article is licensed under a Creative Commons Attribution 4.0 International License, which permits use, sharing, adaptation, distribution and reproduction in any medium or format, as long as you give appropriate credit to the original author(s) and the source, provide a link to the Creative Commons licence, and indicate if changes were made. The images or other third party material in this article are included in the article's Creative Commons licence, unless indicated otherwise in a credit line to the material. If material is not included in the article's Creative Commons licence and your intended use is not permitted by statutory regulation or exceeds the permitted use, you will need to obtain permission directly from the copyright holder. To view a copy of this licence, visit http://creativeco mmons.org/licenses/by/4.0/. The Creative Commons Public Domain Dedication waiver (http://creativecommons.org/publicdomain/ zero/1.0/) applies to the data made available in this article, unless otherwise stated in a credit line to the data. 
of lupins in the genus Lupinus [11, 12]. Lupin seeds are used in breadmaking, biscuits, pasta products, and a variety of other food products [13]. The food items containing the five nuraceuticals described in the present study are widely consumed in Ethiopia and elsewhere in other parts of the world. And therefore they were selected and evaluated against the human colon and leukaemia cancer cell lines. The colonrectal cancer (1.8 million cases) stands third in terms of affecting human health worldwide [1]. As our ongoing effort to search for active compounds, we also evaluated the nutraceuticals against the leukaemia cancer cell lines.

\section{Main text \\ Methods \\ Chemicals and cell lines}

Allyl isothiocyanate, beta-carotene, caffeine, capsaicin, vinblastine sulfate, fetal bovine serum (FBS), dimethyl sulfoxide (DMSO), and 3-(4,5-dimethylthiazol- 2-yl)2,5-diphenyl-tetrazolium bromide (MTT) were purchased from Sigma-Aldrich GmbH, Steinheim, Germany. Lupanine was obtained from our laboratory (MW laboratory) which was extracted from Lupinus species previously [12]. RPMI-1640, DMEM, penicillin-streptomycin, trypsin-EDTA, and L-glutamine were purchased from Gibco, Karlsruhe, Germany.

Two adherent cancer cells (HCT 116, wild type colon cancer cells and HCT 116 p53-/-, p53 knocked out colon cancer cells) and two other cancer cells in suspension (CEM/CCRF, T-lymphoblastic leukemia and CEM/ ADR5000, T-lymphoblastic leukemia over-expressing P-gp) have been routinely cultured in our laboratory for various research works. HCT 116 p $53-/-$, p53 cells were obtained from Prof. Stefan Wölfl group, Institute of Pharmacy and Molecular Biotechnology, Heidelberg University. CEM/ADR5000 and CEM/CCRF cell lines were originally obtained from Professor T. Efferth, Department of Pharmaceutical Biology, University of Mainz, Germany, and maintained in Prof. M. Wink's laboratory, Institute of Pharmacy and Molecular Biotechnology, Heidelberg University.

\section{Cell culture}

The human cells, CEM/CCRF cells and P-gp overexpressing CEM/ADR 5000, were cultured in RPMI 1640 medium supplemented with $10 \%$ (v/v) FBS, 2 mM L-glutamine, and $100 \mathrm{U} / \mathrm{ml}$ penicillin, and $100 \mathrm{~g} / \mathrm{ml}$ streptomycin.

HCT 116 cell lines were maintained in DMEM supplemented with $10 \%(\mathrm{v} / \mathrm{v}) \mathrm{FBS}, 2 \mathrm{mM}$ L-glutamine, 100 $\mathrm{U} / \mathrm{ml}$ penicillin, and $100 \mathrm{~g} / \mathrm{ml}$ streptomycin. HCT 116 cells were detached from the culture vessel by adding
trypsin-EDTA for $5 \mathrm{~min}$. Cells were cultivated at $37^{\circ} \mathrm{C}$, $5 \% \mathrm{CO}_{2}$, and $95 \%$ humidity.

\section{Cytotoxicity assays}

Cells growing in logarithmic growth phase were counted using haemocytometer and then the number of cells to be seeded to 96 -well plates were adjusted at $5 \times 10^{3} / \mathrm{ml}$. HCT 116 and HCT 116 p53-/-were then incubated for $24 \mathrm{~h}$ at $37{ }^{\circ} \mathrm{C}, 5 \% \mathrm{CO}_{2}$. Stock solutions of test compounds were prepared using DMSO. Ten different concentrations of the test compounds which were diluted in two-fold fashion in the medium were then added to the wells and incubated further for $48 \mathrm{~h}$ [14] and the viability of the cells was determined using the MTT assay [15]. MTT solution $(0.5 \mathrm{mg} / \mathrm{ml})$ was added to wells and the optimum incubation of the HCT 116 cells with MTT was $3 \mathrm{~h}$. After removing the liquid from the wells, $100 \mu \mathrm{l}$ of DMSO was added to dissolve the formazan crystals produced by the cells. The 96-well plates were shaken for $10 \mathrm{~min}$ and the optical density was measured at $570 \mathrm{~nm}$ using a Tecan microplate reader (Crailsheim, Germany). Unlike HCT 116 cells, CEM/CCRF and CEM/ADR 5000 cells were seeded to the 96 -wells at $5 \times 10^{4} / \mathrm{ml}$ and then treated with test compounds for $48 \mathrm{~h}$. The optimum incubation time of these cells with MTT was $4 \mathrm{~h}$. Each test compound was evaluated in triplicate and repeated at least two times. The $50 \%$ inhibitory concentration $\left(\mathrm{IC}_{50}\right)$ of each test compound against the cancer cells was determined using SigmaPlot 11.0 software (Systat Software Inc., San Jose, CA, USA).

\section{Results and discussion}

There is ample evidence that mutations in the p53 tumor-suppressor gene are prevalent in human cancers [16] and cells bearing these mutations are rendered to be relatively resistant to drugs. Our results corroborate this feature in which we showed that p53 knockout (p53-/-) HCT 116 cells were more resistant to allyl isothiocyanate (AITC) than their counterpart p53 wild type $(p 53+/+)$ (Table 1$)$. Reactivating p53 mutant to wild type tumor-suppressive function was possible in cancer cells (e.g. SK-BR-3 cells) using other types of isothiocyanates (e.g. phenethyl isothiocyanate PEITC) both in vitro and in vivo. It was shown that PEITC induces apoptosis by restoring p53 wild type conformation in mutant cells, revealing a new mechanism of action for a dietary-related compound against cancer cells [16]. However, Pappa et al. [17] suggested that PEITC induces apoptosis in both types of HCT 116 cells in a p53-independent manner. In rat model, AITCrich mustard seed powder at $71.5 \mathrm{mg} / \mathrm{kg}$ oral dose appeared to be more robust than that of pure AITC and 
Table 1 Anti-proliferative activity of some nutraceutical compounds against human colon cancer and lymphoblastic leukemia cell lines

\begin{tabular}{|c|c|c|c|c|}
\hline \multirow[t]{2}{*}{ Compound } & \multicolumn{3}{|c|}{$I C_{50}(\mu \mathrm{M})$} & \multirow[b]{2}{*}{ CEM/ADR5000 } \\
\hline & HCT116 & HCT116 p53-/- & CEM/CCRF & \\
\hline Allyl isothiocyanate & $162.92 \pm 1.68$ & $>500$ & $155.76 \pm 0.62$ & $194.99 \pm 3.87$ \\
\hline$\beta$-Carotene & $139.53 \pm 5.72$ & $34.94 \pm 0.47$ & $34.46 \pm 1.2$ & $220.58 \pm 12.25$ \\
\hline Caffeine & $>500$ & $332.07 \pm 14.05$ & $444.71 \pm 8.29$ & $>500$ \\
\hline Capsaicin & $22.21 \pm 0.49$ & $19.67 \pm 0.06$ & $64.56 \pm 2.40$ & $122.98 \pm 0.10$ \\
\hline Lupanine & $>500$ & $>500$ & $>500$ & $>500$ \\
\hline Vinblastine sulfate & 0.81 & $<0.015$ & 0.14 & 6.37 \\
\hline
\end{tabular}

inhibited bladder cancer growth by $34.5 \%$ and blocked muscle invasion by $100 \%$, suggesting the anticancer properties of nutraceuticals [18].

In our present study, CEM/ADR5000 cells were also more resistant to AITC than CEM/CCRF cells $(194.99 \pm 3.87 \mu \mathrm{M}$ versus $155.76 \pm 0.62 \mu \mathrm{M})$. CEM/ ADR5000 cells are known to overexpress transmembrane efflux pumps such as ATP-binding cassette $(\mathrm{ABC})$ transporters (e.g. p-gp, BCRP and ABCB5). Although multidrug resistance (MDR) is a multi-factorial process, the current finding, among others, might be ascribed to P-gp as we know from the very beginning that the cultured CEM/ADR5000 cells do overexpress P-gp [19]. Generally, the isothiocyanates are capable of forming covalent bonds with amino groups of amino acid residues (e.g., lysine, arginine) of proteins and also with primary amino groups of DNA bases that would result in protein and DNA alkylation. This alkylation property of isothiocyanates in part explains their mechanism of action for their superb biological activity [20].

In our study, the $\mathrm{IC}_{50}$ ratio $\left(\mathrm{IC}_{50}\right.$ against $(\mathrm{p} 53-/-)$ HCT 116 to $\mathrm{IC}_{50}$ against (p53+/+) HCT 116)) clearly show that p53 knockout HCT116 cells were about four times more sensitive to $\beta$-carotene than p53 wild type HCT 116 cells, suggesting the use of this compound against colon cancers cells like HCT 116 bearing p53 mutations. A number of studies have shown anti-proliferative activity of $\beta$-carotene against different types of cancer. A recent study by Kim et al. [21] showed that $\beta$-carotene elevated histone $\mathrm{H} 3$ and $\mathrm{H} 4$ acetylation upon the treatment of HCT 116 colon cancer stem cells, which is suggestive of an epigenetic modification for anti-proliferative activity of $\beta$-carotene.

In the present study, the leukemia cell lines CEM/ CCRF cells were more sensitive to $\beta$-carotene than their corresponding drug resistant CEM/ADR5000 cells. We have shown previously that carotenoids (e.g., $\quad \beta$-carotene) as competitive inhibitors of
$\mathrm{ABC}$-transporter with the ability of reversing MDR in P-gp expressing cells, which is suggestive of their utilization as adjuvants in chemotherapy [22].

Caffeine is the least active nutraceuticals next to lupanine against the four cancer types tested (Table1). Higher concentrations of caffeine were required to have antiproliferative activity against P53 knockout HCT 116 colon cancer cells and CEM/CCRF leukemia cells. $\mathrm{IC}_{50}$ values of caffeine against p53 wild type $\mathrm{HC} 116$ and CEM/ ADR5000 were even higher than the highest concentration tested $(500 \mu \mathrm{M})$. Kaplanek et al. [23] evaluated caffeine up to $25 \mu \mathrm{M}$ for $72 \mathrm{~h}$ and found $\mathrm{IC}_{50}$ to be higher than $25 \mu \mathrm{M}$ against seven cancer cell lines including the four cancer cell types what we investigated currently. Nevertheless, these authors demonstrated a significant suppressing effect on proliferation by increasing the doses of caffeine (the maximum inhibition being achieved at $5000 \mu \mathrm{M})$. Quite recently in our laboratory, we demonstrated caffeine as having protective effect against acute oxidative stress and extending the lifespan of Caenorhabditis elegans worms [24].

Capsaicin is the most active nutraceutical compound against the four types of cancer cell lines (Fig. 1) (Additional file 1: Additional graphs). Its highest cytotoxicity activity was exerted against p53 knockout HCT116 cell line (IC50: $19.67 \mu \mathrm{M}$ ), indicating these types of cells to be more sensitive to capsaicin than their corresponding p53 wild type HCT116 cells. A study by Senawong et al. [25] demonstrated the anti-proliferative activity of capsaicin without cell-cycle arrest property against HCT 116 cells. Furthermore, it was shown that pepper seed extract, at a concentration of $500 \mu \mathrm{g} / \mathrm{ml}$, exhibited greater anti-proliferative activity (96.8\%) and increased apoptotic cell population by 2.2-fold in HCT 116 cell line [26]. Like AITC discussed above, capsaicin was shown to restore wild type p53 activities by degrading mutant $\mathrm{p} 53$ protein in other human cancer lines U373 (glioblastoma) and SKBR3 (breast cancer) carrying p53 mutation, rendering cancer cells to be more susceptible to cancer drugs [27]. 

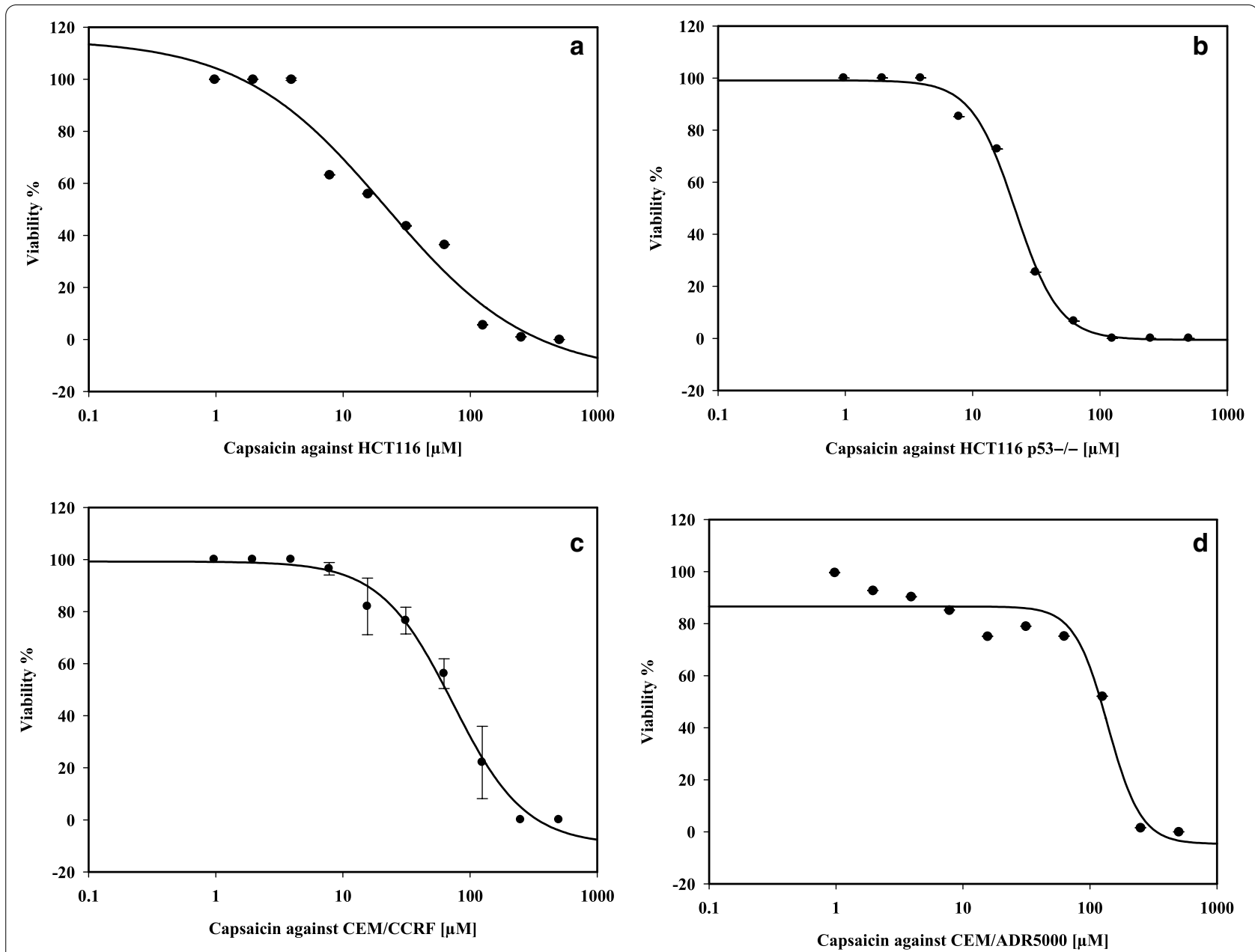

Fig. 1 The anti-proliferative activity of capsaicin against a HCT 116 p53 wild type $\mathbf{b}$ HCT 116 P53-/- c CEM/CCRF d CEM/ADR5000 cancer lines

However, caution should be taken in using capsaicin at low concentration for the treatment of colon cancer as it was confirmed that it enhanced both migratory and invasive capability of HCT 116 cells both in vitro and in vivo $[28,29]$.

CEM/CCRF cells were about two times more sensitive to capsaicin than their corresponding CEM/ADR5000 cells. In this study, it was worth noting that, compared to other nutraceutical compounds tested against drug resistant CEM/ADR5000, capsaicin exerted its cytotoxicity with the lowest $\mathrm{IC}_{50}$ value of $122.98 \mu \mathrm{M}$. Cetintas et al. [30] also found a comparable finding $\left(\mathrm{IC}_{50}=80 \mu \mathrm{M}\right.$ using WST-1 assay) in which they showed the anti-proliferative activity and apoptosis induction property of capsaicin in CEM/CCRF cells evidenced by an increase caspase-3 activity and a decrease in Bcl-2 gene mRNA and protein expression. Like $\beta$-carotene, we showed previously in our laboratory the ability of capsaicin reversing multidrug resistance in P-gp overexpressing Caco-2 and CEM/ ADR5000 cell lines [14].

Lupanine is the least active nutraceutical compound tested against the four cancer cell lines and its $\mathrm{IC}_{50}$ value could not be calculated as it was greater than the maximum concentration, $500 \mu \mathrm{M}$, tested. No other study, other than ours, reported the effect of this compound against cancer cell lines. However, lupanine and other quinolizidine alkaloids (QA) are neurotoxins, affecting acetylcholine receptors and ion channels. And it is therefore only those lupin seeds with low concentrations of QA (below $200 \mu \mathrm{g} / \mathrm{g}$ seeds) are allowed for human consumption [31].

In conclusion, capsaicin is the most potent anti-proliferative nutraceutical followed by beta-carotene. Our results and other previous findings showed that the high concentration of capsaicin as having potent antiproliferative activity without inducing migratory and 
invasive property of colon cancer cells both in vitro and in vivo.

\section{Limitation}

The cytotoxicity assay was assessed using only MTT, which is not sensitive to minor changes. Moreover, additional data should have been presented using microscope which show the changes in cells to explore mechanisms by which nutraceutical compounds caused cell death.

\section{Supplementary Information}

The online version contains supplementary material available at https://doi. org/10.1186/s13104-020-05435-1.

Additional file 1. Additional graphs.

\section{Abbreviations}

AITC: Allyl isothiocyanate; DMSO: Dimethyl sulfoxide; $I C_{50}: 50 \%$ Inhibitory concentration of test compound; PEITC: Phenethyl isothiocyanate; MTT: 3-(4,5-Dimethylthiazol-2-yl)-2,5-diphenyl-tetrazolium bromide.

\section{Acknowledgements}

The authors would like to thank Deutscher Akademischer Austauschdienst (DAAD) for giving scholarship to EN.

\section{Author's contributions}

EN and MW are responsible for conception of the idea. SK is responsible for set up of the experiment. EN is responsible for data collection. EN, SK, and $\mathrm{MW}$ are responsible for data analysis and interpretation. EN is responsible for draft manuscript preparation. SK and MW are responsible for reviewing the manuscript. All authors read and approved the final manuscript.

\section{Funding}

The authors received no specific funding for this work.

\section{Availability of data and materials}

The readers may contact the corresponding author to access the raw data used for the calculation of IC50 values using Sigmaplot11.

\section{Ethics approval and consent to participate}

Ethical clearance was not necessary and not sought from the Institutional Review Board of Heidelberg University as the experiment was done on cancer lines in vitro, not involving human beings.

\section{Consent for publication}

Not applicable.

\section{Competing interests}

The authors declare that they have no competing interests.

\footnotetext{
Author details

${ }^{1}$ Department of Biology, Science College, Bahir Dar University, P.O.Box 79, Bahir Dar, Ethiopia. ${ }^{2}$ Biotechnology Research Institute, Bahir Dar University, P.O.Box 79, Bahir Dar, Ethiopia. ${ }^{3}$ Institute of Pharmacy and Molecular Biotechnology, Heidelberg University, Im Neuenheimer Feld 364, 69120 Heidelberg, Germany.
}

Received: 22 October 2020 Accepted: 24 December 2020 Published online: 07 January 2021

\section{References}

1. WHO. Cancer. https://www.who.int/news-room/fact-sheets/detail/ cancer. Accessed 12 Sep 2018

2. Martinez ME, Marshall JR, Giovannucci E. Diet and cancer prevention: the roles of observation and experimentation. Nature Rev Cancer. 2008;8:694-703.

3. Shukla Y, George J. Combinatorial strategies employing nutraceuticals for cancer development. Ann NY Acad Sci. 2011;1229:162-75.

4. Ida S, Hiki N, Cho H, Sakamaki K, Ito S, Fujitani K, et al. Randomized clinical trial comparing standard diet with perioperative oral immunonutrition in total gastrectomy for gastric cancer. BJS. 2017;104:377-83.

5. Kessler ER, Su LJ, Gao D, Torkko KC, Wacker M, Anduha M, et al. Phase II trial of Acai juice product in biochemically recurrent prostate cancer. Integr Cancer Ther. 2018;17:1103-8.

6. Lane JA, Er V, Avery KNL, Horwood J, Cantwell M, Caro GP, et al. Prodiet: a phase II randomized placebo controlled trial of green tea catechins and lycopene in men at increased risk of prostate cancer. Cancer Prev Res. 2018;11:687-96.

7. Charron CS, Clevidence BA, Albaugh GA, Kramer MH, Vinyard BT, Milner JA, Novotny JA. Assessment of DNA damage and repair in adults consuming allyl isothiocyanate or Brassica vegetables. J Nutr Biochem. 2013;24:894-902.

8. Johnson EJ. The role of carotenoids in human health. Nutr Clin Care. 2002:5:56-65.

9. Verster JC, Koenig J. Caffeine intake and its sources: a review of national representative studies. Crit Rev Food Sci Nutr. 2018;58:1250-9.

10. Chapa-Oliver AM, Mejia-Teniente L. Capsaicin: from plants to a cancersuppressing agent. Molecules. 2016;21:931.

11. Wink M, Witte L, Hartmann T, Theuring C, Volz V. Accumulation of quinolizidine alkaloids in plants and cell suspension cultures: genera Lupinus, Cytisus, Baptisia, Genista, Laburnum, and Sophora. Planta Med. 1983;48:253-7.

12. Ganzera M, Krüger A, Wink M. Determination of quinolizidine alkaloids in different Lupinus species by NACE using UV and MS detection. J Pharm Biomed Anal. 2010;53:1231-5.

13. Mohamed AA, Rayas-Duarte P. Composition of Lupinus albus. Cereal Chem. 1995;72:643-7.

14. Li H, Krstin S, Wang S, Wink M. Capsaicin and piperine can reverse multidrug resistance in multidrug resistant cancer cells by competing P-glycoprotein activity. Molecules. 2018;23:557.

15. Mosmann T. Rapid colorimetric assay for cellular growth and survival: application to proliferation and cytotoxicity assays. J Immunol. 1983;65:55-63.

16. Aggarwal M, Saxena R, Sinclair E, Fu Y, Jacobs A, Dyba M, et al. Reactivation of mutant p53 by a dietary-related compound phenethyl isothiocyanate inhibits tumor growth. Cell Death Differ. 2016;23:1615-27.

17. Pappa G, Lichtenberg M, lori R, Barillari J, Bartsch H, Gerhauser C. Comparison of growth inhibition profiles and mechanisms of apoptosis induction in human colon cancer cell lines by isothiocyanates and indoles from Brassicaceae. Mutat Res. 2006;599:76-87.

18. Bhattacharya A, Li Y, Wade KL, Paonessa JD, Fahey JW, Zhang Y. Allyl isothiocyanate-rich mustard seed powder inhibits bladder cancer growth and muscle invasion. Carcinogenesis. 2010;31:2105-10.

19. Saeed MEM, Mahmoud N, Sugimoto Y, Efferth T, Abdel-Aziz H. Molecular determinants of sensitivity or resistance of cancer cells to ward sanguinarine. Front Pharmacol. 2018;9:136.

20. Wink M. Evolutionary advantage and molecular modes of action of multi-component mixtures used in phytomedicine. Curr Drug Metab. 2008;9:996-1009.

21. Kim D, Kim Y, Kim Y. Effects of $\beta$-carotene on expression of selected microRNAs, histone acetylation, and DNA methylation in colon cancer stem cells. J Cancer Prev. 2019;24:224-32.

22. Eid SY, El-Readi MZ, Wink M. Carotenoids reverse multidrug resistance by interfering with $\mathrm{ABC}$-transporters in cancer cells. Phytomedicine. 2012;19:977-87.

23. Kaplanek R, Jakubek M, Rak J, Kejik Z, Havlik M, Dolensky B, et al. Caffeinehydrazones as anticancer agents with pronounced selectivity toward T-lymphoblastic leukemia cells. Bioorg Chem. 2015;60:19-29.

24. Li H, Roxo M, Cheng X, Zhang S, Cheng H, Wink M. Pro-oxidant and lifespan extension effects of caffeine and related methylxanthines in Caenorhabditis elegans. Food Chem. 2019;X1:100005. 
25. Senawong T, Wongphakham P, Saiwichai T, Phaosiri C, Kumboonma P. Histone deacetylase inhibitory activity of hydroxycapsaicin, a synthetic derivative of capsaicin, and its cytotoxic effects against human colon cancer cell lines. Turk J Biol. 2015;39:370-9.

26. Jeon G, Choi Y, Lee SM, Kim Y, Oh M, Jeong HS, Lee J. Antioxidant and antiproliferative properties of hot pepper (Capsicum annuum L.) seeds. J Food Biochem. 2012;36:595-603.

27. Garufi A, Pistritto G, Cirone M, D'Orazi G. Reactivation of mutant p53 by capsaicin, the major constituent of peppers. J Exp Clin Cancer Res. 2016;35:136.

28. Liu NH, Hsieh PF, Hsieh MK, Zeng ZM, Cheng HL, Liao JW, Chueh PJ. Capsaicin-mediated tNOX (ENOX2) Up-regulation enhances cell proliferation and migration in vitro and in vivo. J Agric Food Chem. 2012;60:2758-65.

29. Yang J, Li TZ, Xu GH, Luo BB, Chen YX, Zhang T. Low-concentration capsaicin promotes colorectal cancer metastasis by triggering ROS production and modulating Akt/mTOR and STAT-3 pathways. Neoplasma. 2013;60:4.
30. Cetintas VB, Kaymaz BT, Aktug H, Oltulu F, Taskiran D. Capsaicin induced apoptosis and gene expression dysregulation of human acute lymphoblastic leukemia CCRF-CEM cells. JBUON. 2014;19:183-90.

31. Wink M. Interference of alkaloids with neuroreceptors and ion channels. In: Rahmann A-u, editor. Bioactive natural products, vol. 11. Amsterdam: Elsevier; 2000. p. 3-129.

\section{Publisher's Note}

Springer Nature remains neutral with regard to jurisdictional claims in published maps and institutional affiliations.
Ready to submit your research? Choose BMC and benefit from:

- fast, convenient online submission

- thorough peer review by experienced researchers in your field

- rapid publication on acceptance

- support for research data, including large and complex data types

- gold Open Access which fosters wider collaboration and increased citations

- maximum visibility for your research: over $100 \mathrm{M}$ website views per year

At BMC, research is always in progress.

Learn more biomedcentral.com/submissions 